\title{
СТУДЕНТСЫКІ ДОСАІДЖЕННЯ
}

УДК 339.54

DOI: $10.26565 / 2524-2547-2020-59-11$

\section{РОЗВИТОК ЗОВНШШНЬОЕКОНОМІЧНОЇ ДІЯАЬНОСТІ УКРАЇНСЬКИХ ПІДПРИСМСТВ В УМОВАХ ГАОБАМІЗАЦІї ЕКОНОМІКИ}

\author{
Бондаренко Наталія Миколаївна \\ кандидат економічних наук, доцент \\ e-mail: bondarenkonatalya1@gmail.com \\ ORCID ID: 0000-0003-4733-8159 \\ Червонченко Киримо Едуардович \\ студент магістратури \\ e-mail: chervonchenko.kirill16@ukr.net \\ ORCID ID: 0000-0003-3908-2202 \\ Дніпровсъкий начіональний університет імені О. Гончара \\ пр.-к. Гагаріна, 72, Дніпро, 49010, Україна
}

У сучасному глобалізованому світі досить потужною силою економічного розвитку виступає міжнародна торгівля, яка охоплює сукупність зовнішньої торгівлі всіх країн світу. Економічний розвиток будь-якої країни неможливий без їі активної участі в торговельних відносинах з іншими країнами світу. Швидке формування глобальної економіки сприяє виникненню низки можливостей для бізнесу, як великого, так і малого. В статті розглянуті як переваги глобалізації економіки, так і їі недоліки. Встановлено, що за сучасних умов технологічного розвитку та стрімких інтеграційних процесів необхідно враховувати їі результати під час формування ефективної політики держави щодо здійснення зовнішньоекономічної діяльності. Країна, що входить до системи глобальних господарських зв'язків має підвищувати свою конкурентоспроможність, мати свої конкурентні переваги задля уникнення впливу негативних факторів.

В роботі показано сучасний стан розвитку зовнішньої торгівці України з іншими країнами світу, досліджено структуру українського експорту та імпорту. Не зважаючи на значне зростання вартості експорту товарів та послуг до країн світу, Україна все ще залишається імпортозалежною країною. Валютна цібералізація сприяла частковому уникненню упередженого став ення $з$ боку іноземних контрагентів, інвесторів та банків, що дозволило українським підприємствам вести повноцінну діяльність на зовнішніх ринках, результатом чого стало значне скорочення негативного зовнішньоторговельного сальдо країни. Новий закон про ваАюту забезпечив в Україні базу дмя вільного руху капіталу, що наблизило країну до європейських стандартів. Проте, не зважаючи на значні послаблення у валютному регулюванні, українські виробники продовжують зіштовхуватися з низкою як внутрішніх, так і зовнішніх перешкод на шляху до активізації експортної діяльності. В статті визначено подальші шияхи розвитку зовнішньоекономічної діяльності вітчизняних підприємств в умовах глобалізації. Проведені дослідження дали змогу встановити, що стабільний розвиток економіки можливий мише при збереженні її відкритості та швидкому розвитку зовнішньої торгівлі.

Ключові слова: зовнішньоекономічна діяльність, міжнародний ринок, глобалізація, експорт, імпорт, вітчизняні підприємства.

JEL Classification: F60; F63; G28.

(C) Бондаренко Н. М., Червонченко К. Е., 2020 


\title{
РАЗВИТИЕ ВНЕШНЕЭКОНОМИЧЕСКОЙ ДЕЯТЕАЬНОСТИ УКРАИНСКИХ ПРЕДПРИЯТИЙ
} В УСАОВИЯХ ГАОБААИЗАЦИИ ЭКОНОМИКИ

\author{
Бондаренко Наталья Никомаевна \\ кандидат экономических наук, доцент \\ e-mail: bondarenkonatalya1@gmail.com \\ ORCID ID: 0000-0003-4733-8159 \\ Червонченко Киримя Эдуардович \\ студент магистратуры \\ e-mail: chervonchenko.kirill16@ukr.net \\ ORCID ID: 0000-0003-3908-2202 \\ Днепровский национапьный университет имени О. Гончара \\ пр.-к. Гагарина, 72, Днепр, 49010, Украина
}

В современном глобализированном мире достаточно мощной силой экономического развития выступает международная торговля, которая охватывает совокупность внешней торговли всех стран мира. Экономическое развитие Аюбой страны невозможно без ее активного участия в торговых отношениях с другими странами мира. Быстрое формирование гмобальной экономики способствует возникновению ряда возможностей для бизнеса, как крупного, так и малого. В статье рассмотрены как преимущества гмобализации экономики, так и ее недостатки. Установцено, что в современных условиях технологического развития и стремительных интеграционных процессов необходимо учитывать ее результаты при формировании эффективной политики государства касательно осуществления внешнеэкономической деятельности. Страна, которая входит в систему глобальных хозяйственных связей, должна повышать свою конкурентоспособность, иметь свои конкурентные преимущества во избежание вАияния негативных факторов.

В работе показано текущее состояние развития внешней торговли Украины с другими странами мира, исследована структура украинского экспорта и импорта. Несмотря на значительный рост стоимости экспорта товаров и услуг в страны мира, Украина все еще остается импортозависимым государством. Валютная миберализация способствовала уменьшению масштабов предвзятого отношения со стороны иностранных контрагентов, инвесторов и банков, что позволило украинским предприятиям вести полноценную деятельность на внешних рынках, результатом чего стало значительное сокращение отрицательного внешнеторгового сальдо страны. Новый закон о валюте обеспечил в Украине базу для свободного движения капитала, приблизив страну к европейским стандартам. Тем не менее, несмотря на значительные послабления в валютном регулировании, украинские производители продолжают сталкиваться с рядом как внутренних, так и внешних препятствий на пути к активизации экспортной деятельности. В статье определены дальнейшие пути развития внешнеэкономической деятельности отечественных предприятий в условиях глобализации. Проведенные исследования позволили установить, что стабильное развитие экономики возможно только в условиях сохранения ее открытости и быстрого развития внешней торговли.

Ключевые слова: внешнеэкономическая деятельность, международный рынок, гмобализация, экспорт, импорт, отечественные предприятия.

JEL Classification: F60; F63; G28.

\section{DEVELOPMENT OF FOREIGN ECONOMIC ACTIVITY OF UKRAINIAN ENTERPRISES UNDER CONDITIONS OF ECONOMIC GLOBALIZATION}

\author{
Natalia Bondarenko \\ PhD (Economics), Associate Professor \\ e-mail: bondarenkonatalya1@gmail.com \\ ORCID ID: 0000-0003-4733-8159 \\ Kyrylo Chervonchenko \\ Undergraduate Student \\ e-mail: chervonchenko.kirill16@ukr.net \\ ORCID ID: 0000-0003-3908-2202 \\ O. Honchar National University of Dnipro \\ 72, BC Gagarina, Dnipro, 49010, Ukraine
}

In today's globalized world, international trade, which covers the totality of foreign trade of all countries of the world, is a powerful force of economic development. The economic development of any country is impossible without its active participation in trade relations with other countries of 
the world. The rapid formation of the global economy contributes to the emergence of a number of opportunities for both large and small businesses. The article considers both advantages and disadvantages of globalization of economy. The article claims that in the current conditions of technological development and rapid integration processes, it is necessary to take into account results of globalization, while forming an effective state policy regarding the realization of foreign trade activities. The country participating in the system of global economic relations should have competitive advantages and improve its competitiveness in order to avoid the impact of negative factors.

The article reveals the current state of the development of Ukraine's foreign trade with other countries of the world, as well as explores Ukraine's exports and imports structure. Despite a significant increase in the cost of exporting goods and services to the world, Ukraine is still an import-dependent country. The currency liberalization contributed to the reduction of prejudice from foreign counterparties, investors and banks, which allowed Ukrainian enterprises to operate fully in foreign markets, which resulted in a significant reduction in the negative foreign trade balance of the country. The new currency law has provided Ukraine with a base for free capital movement, which brought the country closer to European standards. However, despite significant easing in foreign exchange regulation, Ukrainian manufacturers continue to face a number of both internal and external obstacles to boosting their export activity. The article defines further ways of development of foreign economic activity of domestic enterprises in the conditions of globalization. It has been established that the stable development of the economy is possible only in the conditions of maintaining its openness and rapid development of foreign trade.

Keywords: Foreign Economic Activity, International Market, Globalization, Export, Import, Domestic Enterprises.

JEL Classification: F60; F63; G28.

Постановка пробцеми. Необхідність використання гмобамьного підходу до ведення бізнесу у сучасному світі зумовлена підвищенням взаємозалежності національних економік та активізацією інтеграційних процесів. У зв'язку з цим багато країн підвищують свою зацікавленість в економічному, виробничому і науково-технічному співробітництві 3 іноземними партнерами. В умовах глобалізації світового господарства зовнішньоекономічна діяльність виконує важливу функцію інтернаціоналізації економіки.

Успіх у реалізації цілей зовнішньоекономічної діяльності підприємства багато в чому залежить від належно обраної стратегії управління, яка має містити у собі рішення, пов'язані з вибором цільових сегментів та способів впливу на них, а також адекватне розуміння вимог споживачів країнпартнерів. Особливості економічного розвитку, що обумовлюються відкритістю економіки України, в поєднанні з процесами глобалізації світового господарства і міжнародних економічних відносин, істотно впливають на цілі, пріоритети та характер розвитку зовнішньоторговельних зв'язків.

Аналіз останніх досліджень і публікацій. Теоретичні та практичні аспекти управціння зовнішньоекономічною діяльністю в умовах глобалізації були відображені у працях таких вітчизняних та закордонних досмідників, як: О. Вцасюк (Вцасюк, 2012), О. Диба (Диба, 2018), Г. Дроздова (Дроздова, 2012), О. Кірієнко (Кірієнко, 2013), Ю. Козак (Козак, 2011; Козак, 2015), I. Рзун (Рзун, 2016), О. Трифонова (Трифонова, 2015) та ін. В перелічених роботах в різних аспектах представлений аналіз переваг та недоліків здійснення зовнішньоекономічної діяльності в контексті росту взаємозв'язку і взаємозацежності національних економік. Проаналізувавши роботи зазначених авторів, можна зробити висновок, що процес глобалізації $€$ доволі суперечливим явищем: деяким країнам він допомагає швидко вийти на передовий рівень, дмя інших - несе у собі неоднозначні наслідки.

За даних умов особливо важливим $є$ досмідження впливу глобалізаційних процесів на зовнішньоекономічну діяльність підприємств України.

Метою роботи $є$ дослідження основних проблем і протиріч, що мають місце при здійсненні зовнішньоекономічної діяльності під впливом процесів глобалізації та визначення подальших шляхів розвитку зовнішньоекономічної діяльності вітчизняних підприємств.

Основні резуцьтати дослідження. Зовнішньоекономічна діяльність $є$ вагомою $\mathrm{i}$ невід'ємною сферою господарської діяцьності всіх учасників ринкових відносин. В умовах глобалізації світового господарства вона виконує важливу функцію інтернаціоналізації економіки (Васюренко, 2012).

ГАобалізація - це комплекс, що охопиює різні сфери світового товариства. Процеси у сфері економіки та фінансів межать в основі глобалізації та являють собою фундамент для глобальних процесів в інших сферах. В основі економічної глобалізації цежать інтернаціоналізація господарського життя та міжнародний подіц праці (Чепінога, 2017). 
Оскільки процеси гмобалізації $є$ довомі складними та багатогранними, вони характеризуються наявністю як переваг (рис. 1), так і недоліків, з якими вкрай складно, а іноді й неможливо боротися. Серед основних недоміків глобалізації виділяють надмірну замежність однієї країни від іншої, коли проблема однієї великої країни стає всесвітньою проблемою. Великим недоліком глобалізації також залишається збільшення нелегальної імміграції, коли нелегальні іммігранти з країн, що розвиваються, не маючи роботи у сво- їй країні, виїжджають, порушуючи законодавство, до більш розвинутих країн.

Деякі виробництва не здатні конкурувати в вільній ринковій системі. Наслідком закриття подібних виробництв стає безробіття, i мюдям досить часто доводиться навчатися новим професіям та змінювати місця роботи.

Країна, що входить до системи гмобальних господарських зв'язків має підвищувати свою конкурентоспроможність, мати свої конкурентні переваги задля уникнення впливу вищезазначених негативних факторів.

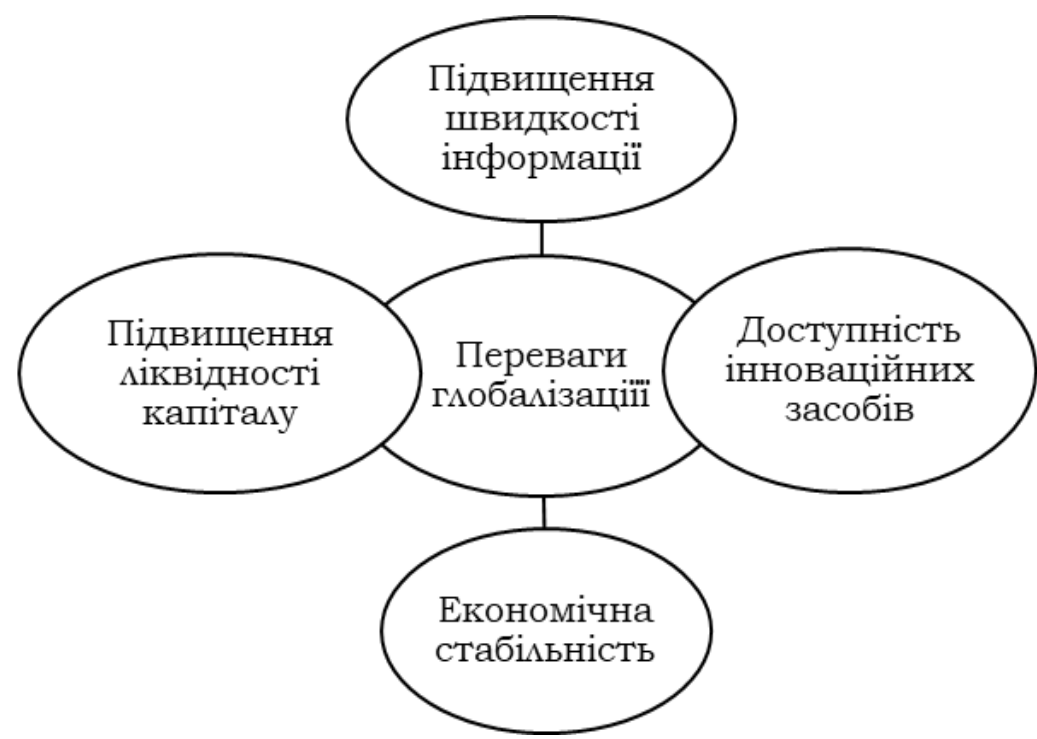

Рис. 1. Переваги від участі у процесах глобалізації

Джеремо: побудовано авторами за даними (Чепінога, 2017)

На сьогодні міжнародна торгівця товарами та послугами відіграє вирішальну роль в економічному розвитку держави. Саме завдяки міжнародній торгівці країни розширюють свої виробничі та споживчі можливості, отримують необхідні внутрішнім споживачам продукти, реалізують профіцит продукції, який не погминається внутрішнім ринком, посилюють конкуренцію на світовому ринку (Диба, 2018).

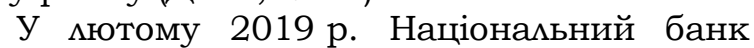
України запровадив нову міберальну систему валютного регулювання, передбачену Законом України "Про валюту і валютні операції" (Верховна Рада України, 2018).

Нове регулювання містить у собі ряд послаблень на валютному ринку, які полегшили ведення бізнесу. 37 мютого 2019 р. було введено в дію понад 20 послаблень, основні 3 них наведені на рис. 2.

Вагомим кроком на шияху до вільного руху капіталу стало також скасування обов'язкового продажу валютних надходжень затверджене Постановою Правміння Національного банку України від 18.06.2019 р. № 78 «Про внесення зміни до Поможення про заходи захисту та визначення порядку здійснення окремих операцій в іноземній валюті" (НБУ, 2019).

У 2019 р. в Україні зовнішньоекономічною діяльністю займалися понад 20 тис. підприємств та майже 152 тис. фізичних осіб підприємців, що контактували 3 235 країнами світу.

Аналітичні дані (Державна служба статистики України, 2020) свідчать, що завдяки діям Національного банку України, направменим на мібералізацію валютних відносин, негативне сальдо зовнішньоторговельного балансу України за результатами 2019 р. скоротилося на 41,5 \% у порівнянні з результатами попереднього року: за підсумками року негативне сальдо складає 3,63 мирд дом. США, у 2018 р. даний показник складав 6,21 мирд дом. США.

У 2019 р. експорт товарів та посиуг становив 63675,6 млн дом. США або $111,2 \%$ у порівнянні із 2018 р., імпорт 67308,7 млн дом. США, або 106,0 \%. Зовнішньоторговельний оборот України у 2019 р. склав 130984,3 млн дол. США, що на 9 \% більше показника 2018 р.

На рис. 3 графічно наведена динаміка зовнішньої торгівлі товарами та послугами в Україні за період з 2012 по 2019 рр. 


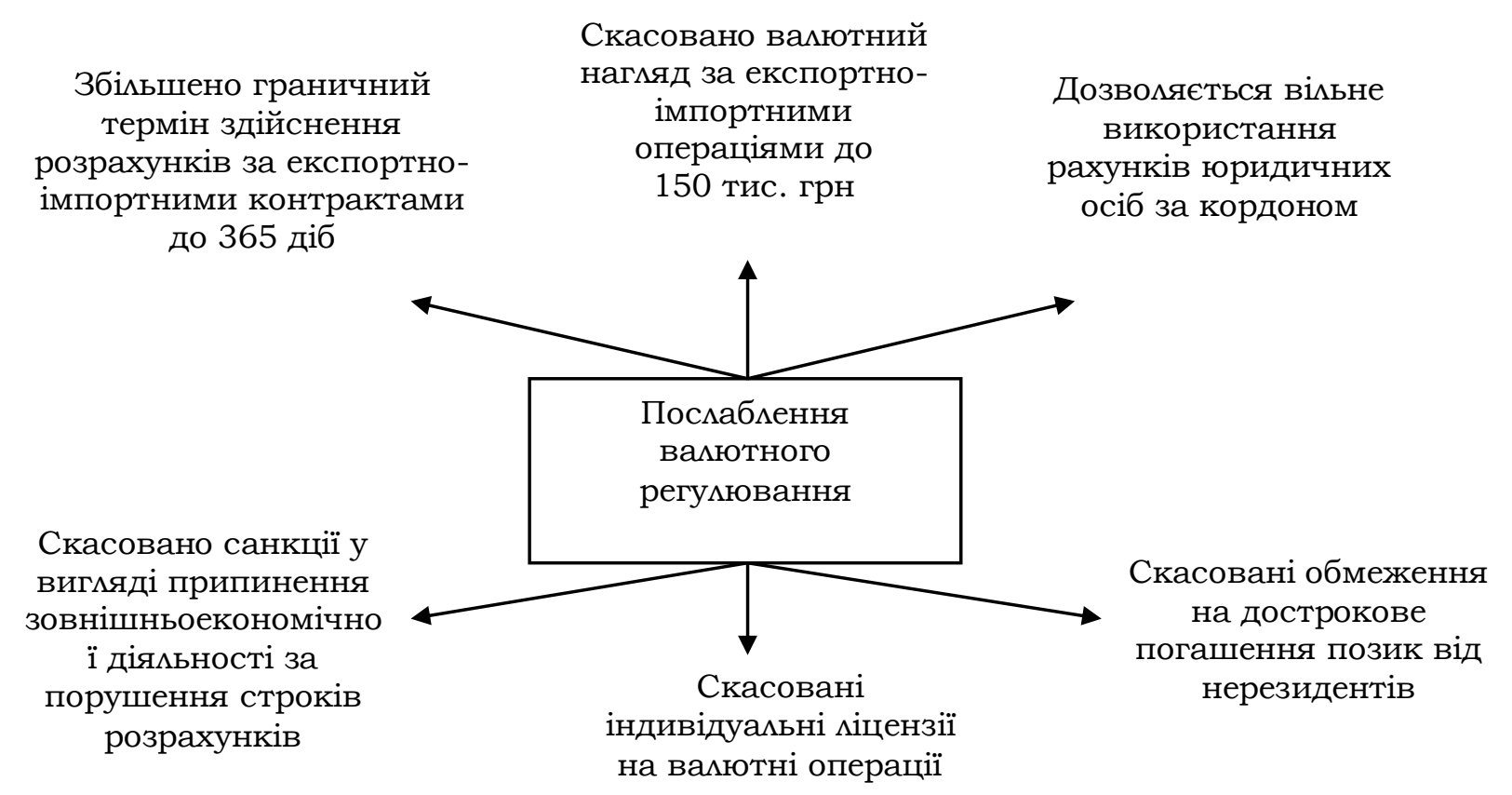

Рис. 2. Основні послаблення на валютному ринку України

Як видно з рис. 3, починаючи з 2017 р. обсяг імпорту товарів та послуг незмінно переважає над їх експортом, в результаті чого країна отримує негативне сальдо зовнішньоторговельного балансу. Значне зменшення обсягів зовнішньої торгівлі у 2014-2016 рр. пояснюється причинами воєнно-політичного й економічного характеру, які стали вирішальними чинниками впливу на рівень зовнішньоекономічної діяльності України.

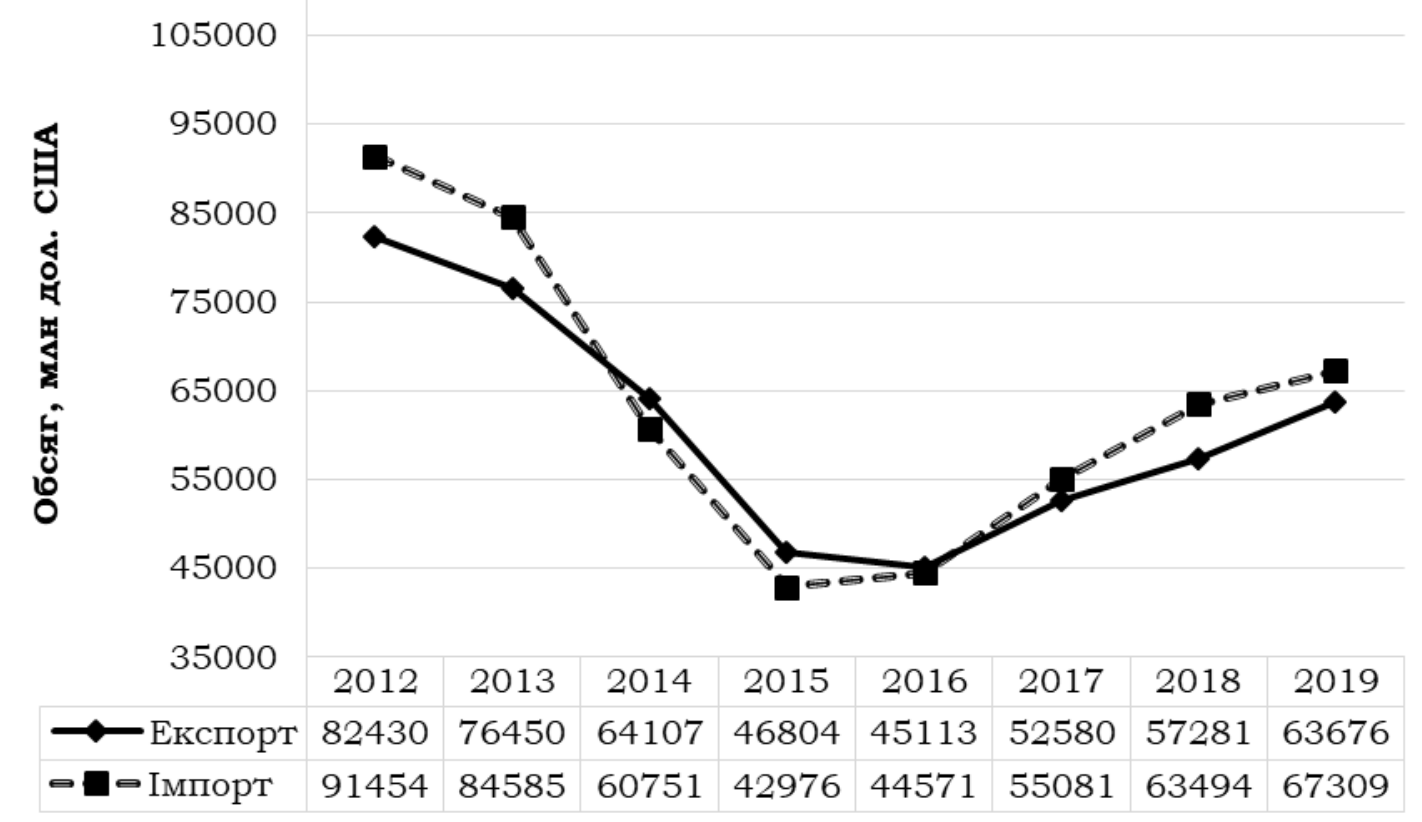

Рис. 3. Динаміка річних обсягів експорту та імпорту України у 2012-2019 рр.

Джерело: побудовано авторами за даними Державної служби статистики України (Державна скужба статистики України, n.d.)

Провідними статтями товарного експорту України у 2019 р. стали продукти росминного походження та недорогоцінні метами та вироби з них, які складають відповідно $25,8 \%$ та 20,5 \% від загального обсягу експортованої закордон продукції (рис. 4).
Як видно з рис. 4, окрім вищезазначеної продукції, значну частку у структурі експорту України також мали мінеральні продукти (9,7\%), жири та олії тваринного або рослинного походження $(9,5 \%)$, машини, обцаднання та механізми, електротехнічне облад- 
нання (8,9 \%). Разом зазначені статті товарного експорту України у 2019 р. становими 74,4 \% від загамьного обсягу експортованої продукції. Варто зазначити, що у 2018 р. основними експортними продуктами України були продукти рослинного походження та недорогоцінні метали та вироби з них, питома вага яких у структурі загального експорту складала відповідно 20,9 \% та 24,6 \%.

Тобто, якщо у 2018 р. основною статтею експорту були недорогоцінні метали, то у 2019 р. провідну позицію займають продукти рослинного походження, що пояснюється зростанням вартості їх експорту на 30,6 \% проти рівня 2018 р.

\section{8 рік}

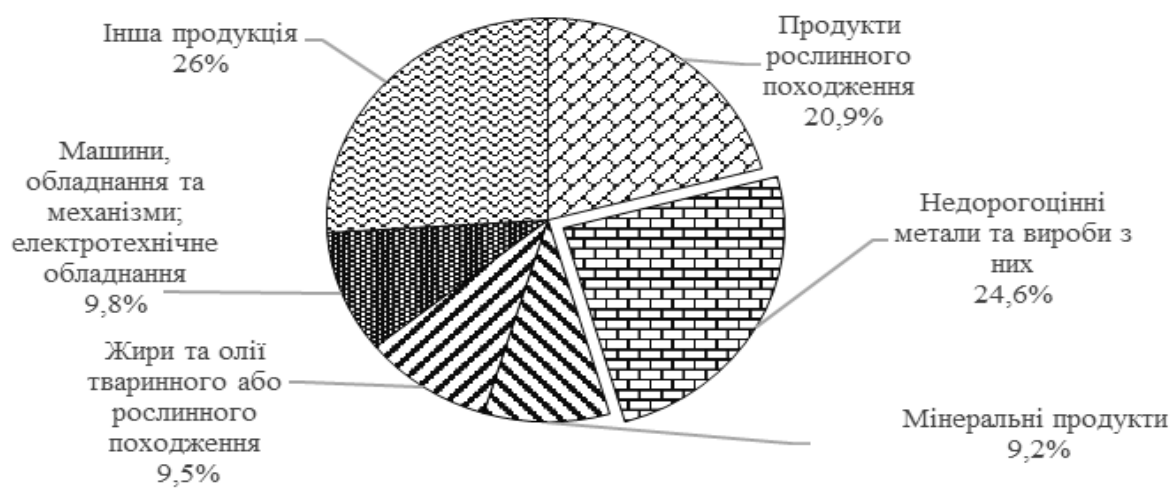

\section{9 рік}

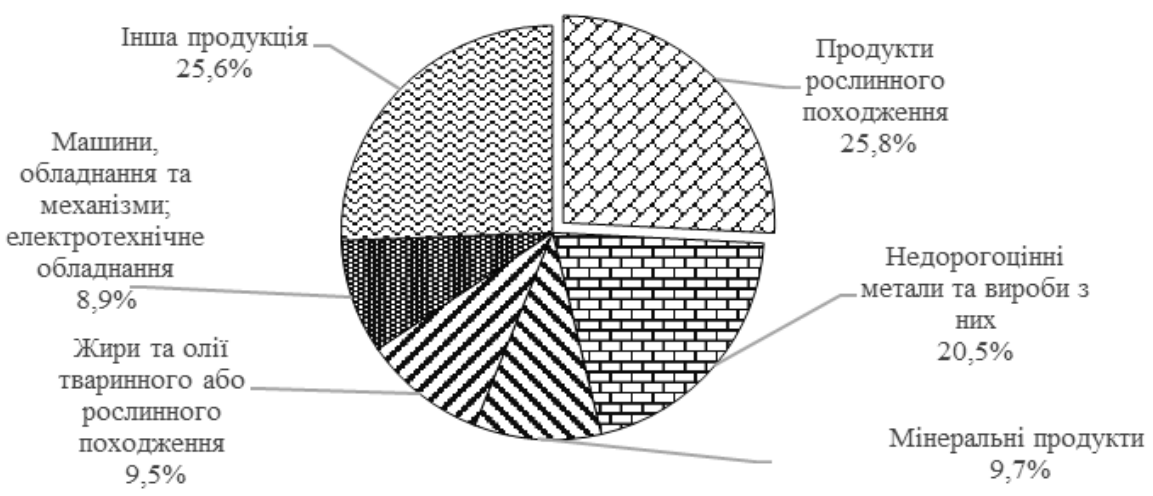

Рис. 4. Товарна структура експорту України у 2018 та 2019 рр.

Джерело: побудовано авторами за даними Державної служби статистики України (Державна служба статистики України, n.d.)

Основним покупцем продукції українських товаровиробників у 2019 р. став Китай - 7,2\% (3593,7 млн дол. США, що на 63,3 \% більше за результат попереднього року) товарного експорту України (табл. 1). Основною експортованою продукцією до Китаю стали руда, шлаки і зола (за 2019 р. 1177451,3 тис. дом. США).

Окрім цього, значна частка експорту продукції припадає на Польщу - 6,6 \%, Російську Федерацію - 6,5\%, Туреччину 5,2 \%, Італію - 4,8 \% та Німеччину - 4,8 \%. Загальна частка експортованої продукції до EC $-41,5 \%$.

Варто відмітити і тенденцію щодо збільшення питомої ваги експорту продукції до таких країн як Нідерланди (від 1,2\% у 2012 р. до $3,7 \%$ у 2019 р.) та Іспанії (від $1,6 \%$ у 2013 р. до 3,0 \% у 2019 р.). Починаючи з 2015 р. спостерігається чітка тенденція до зростання частки експорту до Білорусі - доля експорту до сусідньої держави збільшилась з 2,3 \% до 3,1\% від загального експорту товарів України.

Закриття російського ринку для багатьох товарів з України стало причиною падіння українського експорту до Російської Федераціi. Проте, попри санкції та напружені відносини між країнами, Російська Федерація залишається одним з основних торговельних партнерів України. 
Основні країни збуту українських товарів у 2012-2019 рр., \%

\begin{tabular}{|l|c|c|c|c|c|c|c|c|}
\hline \multicolumn{1}{|c|}{ Країна } & 2012 р. & 2013 р. & 2014 р. & 2015 p. & 2016 p. & 2017 p. & 2018 p. & 2019 p. \\
\hline Білорусь & 3,3 & 3,1 & 3,0 & 2,3 & 2,5 & 2,6 & 2,8 & 3,1 \\
\hline Єгипет & 4,2 & 4,4 & 5,3 & 5,5 & 6,2 & 4,2 & 3,3 & 4,5 \\
\hline Індія & 3,3 & 3,1 & 3,4 & 3,8 & 5,2 & 5,1 & 4,6 & 4,0 \\
\hline Іспанія & 2,2 & 1,6 & 2,2 & 2,7 & 2,8 & 2,9 & 2,9 & 3,0 \\
\hline Італія & 3,6 & 3,8 & 4,6 & 5,2 & 5,3 & 5,7 & 5,6 & 4,8 \\
\hline Китай & 2,6 & 4,3 & 5,0 & 6,3 & 5,0 & 4,7 & 4,6 & 7,2 \\
\hline Нідерланди & 1,2 & 1,7 & 2,1 & 2,4 & 2,7 & 3,9 & 3,4 & 3,7 \\
\hline Німеччина & 2,4 & 2,5 & 3,0 & 3,5 & 3,9 & 4,1 & 4,7 & 4,8 \\
\hline Польща & 3,7 & 4,1 & 4,9 & 5,2 & 6,1 & 6,3 & 6,9 & 6,6 \\
\hline $\begin{array}{l}\text { Російська } \\
\text { Федерація }\end{array}$ & 25,6 & 23,7 & 18,2 & 12,7 & 9,9 & 9,1 & 7,7 & 6,5 \\
\hline Туреччина & 5,4 & 6,0 & 6,6 & 7,3 & 5,6 & 5,8 & 5,0 & 5,2 \\
\hline Угрщина & 2,2 & 2,5 & 2,8 & 2,4 & 2,9 & 3,1 & 3,5 & 3,1 \\
\hline Країни ЄС, всього & 25,7 & 25,0 & 28,1 & 33,8 & 37,1 & 40,5 & 42,6 & 41,5 \\
\hline $\begin{array}{l}\text { Країни СНД, } \\
\text { всього }\end{array}$ & 36,8 & 34,8 & 27,4 & 24,2 & 21,6 & 20,3 & 14,8 & 13,0 \\
\hline
\end{tabular}

Джерело: побудовано авторами за даними Державної служби статистики України (Державна служба статистики України, n.d.)

Серед пріоритетних імпортерів товарів до України у 2019 р. став Китай: було імпортовано товарів на 9195,6 мин дом. США, що становить 15,1 \% загального обсягу імпорту (табл. 2). Основними імпортованими товарами 3 Китаю $\epsilon$ електричні машини (3175 мин дом. США) та ядерні реактори, котАи, машини (1548,7 млн дом. США). Загамом 3 Китаю було імпортовано на 20,9\% більше товару, ніж у минулому році. За да- ними табл. 2 видно, що частка китайських товарів на українському ринку зростає: 3 2012 р. по 2016 р. доля імпортованих з Китаю товарів серед всього товарного імпорту України зросла $з$ 9,2 \% до 11,9 \%. У 2017 р. спостерігався невемикий спад імпорту китайської продукції, проте вже у 2018 р. їі частка склала 13,3 \%, а у 2019 р. Китай став основним торговим партнером України.

Таблиця 2

Основні країни-імпортери товарів в Україну та їх частка

у загальному обсязі українського імпорту, \%

\begin{tabular}{|l|c|c|c|c|c|c|c|c|}
\hline \multicolumn{1}{|c|}{ Країна } & 2012 p. & 2013 p. & 2014 p. & 2015 p. & 2016 p. & 2017 p. & 2018 p. & 2019 p. \\
\hline Китай & 9,2 & 9,8 & 9,9 & 10,1 & 11,9 & 11,4 & 13,3 & 15,1 \\
\hline $\begin{array}{l}\text { Російська } \\
\text { Федерація }\end{array}$ & 32,9 & 30,5 & 23,3 & 20,0 & 13,1 & 14,5 & 14,2 & 11,5 \\
\hline Німеччина & 8,1 & 8,8 & 9,9 & 10,6 & 11 & 11 & 10,5 & 9,9 \\
\hline Помьща & 4,3 & 5,3 & 5,6 & 6,2 & 6,9 & 7,0 & 6,4 & 6,8 \\
\hline Білорусь & 6,1 & 4,7 & 7,3 & 6,5 & 7,1 & 6,5 & 6,6 & 6,2 \\
\hline США & 3,5 & 3,6 & 3,5 & 3,9 & 4,3 & 5,0 & 5,2 & 5,4 \\
\hline Туреччина & 2,2 & 2,3 & 2,4 & 2,3 & 2,8 & 2,6 & 3,0 & 3,9 \\
\hline Італія & 2,7 & 2,7 & 2,8 & 2,6 & 3,5 & 3,3 & 3,6 & 3,4 \\
\hline Франція & 2,0 & 2,3 & 2,3 & 2,4 & 3,9 & 3,2 & 2,6 & 2,7 \\
\hline Угрщина & 1,4 & 1,8 & 2,7 & 4,3 & 2,0 & 2,3 & 2,2 & 2,0 \\
\hline СС & 31,1 & 35,2 & 38,0 & 42,0 & 42,4 & 43,1 & 40,2 & 41,1 \\
\hline СНД & 41,3 & 36,6 & 31,7 & 26,2 & 20,7 & 22 & 23,1 & 19,5 \\
\hline
\end{tabular}

Джерело: побудовано авторами за даними Державної скужби статистики України (Державна служба статистики України, n.d.)

Попри скорочення імпорту товарів із Російської Федерації на 13,6 \% (з 8090,4 мАн дом. США у 2018 р. до 6986,2 млн дом. США у 2019 р. (Державна служба статистики України, n.d.), імпортні закупки із даної держави продовжують займати значну частку серед імпортних опе- рацій України. Так, за підсумками 2019 р. імпорт із РФ займає 11,5 \% всієї імпортованої продукції. Основний продукт імпорту нафта та продукти її перегонки.

Слід відмітити тенденцію до росту частки імпортованої продукції з США: за аналізований період домя імпортованої про- 
дукції з даної країни серед загального обсягу імпорту підвищилась з 3,5 \% до 5,4 \%.

Товарна структура імпорту України за 2019 та 2018 рр. надана на рис. 5.

За даними Державної служби статистики України, провідною статтею товарного імпорту є машини, обладнання та механізми, електротехнічне обладнання (13307,4 млн дом.
США, що на $11 \%$ більше, ніж у 2018 р. та складає 21,9 \% від загального імпорту товарів). Майже стільки ж було витрачено у 2019 р. на імпорт мінеральних продуктів (12983,7 мин дом. США). Значно скороти$\Lambda$ ись обсяги імпорту недорогоцінних металів та виробів з них.

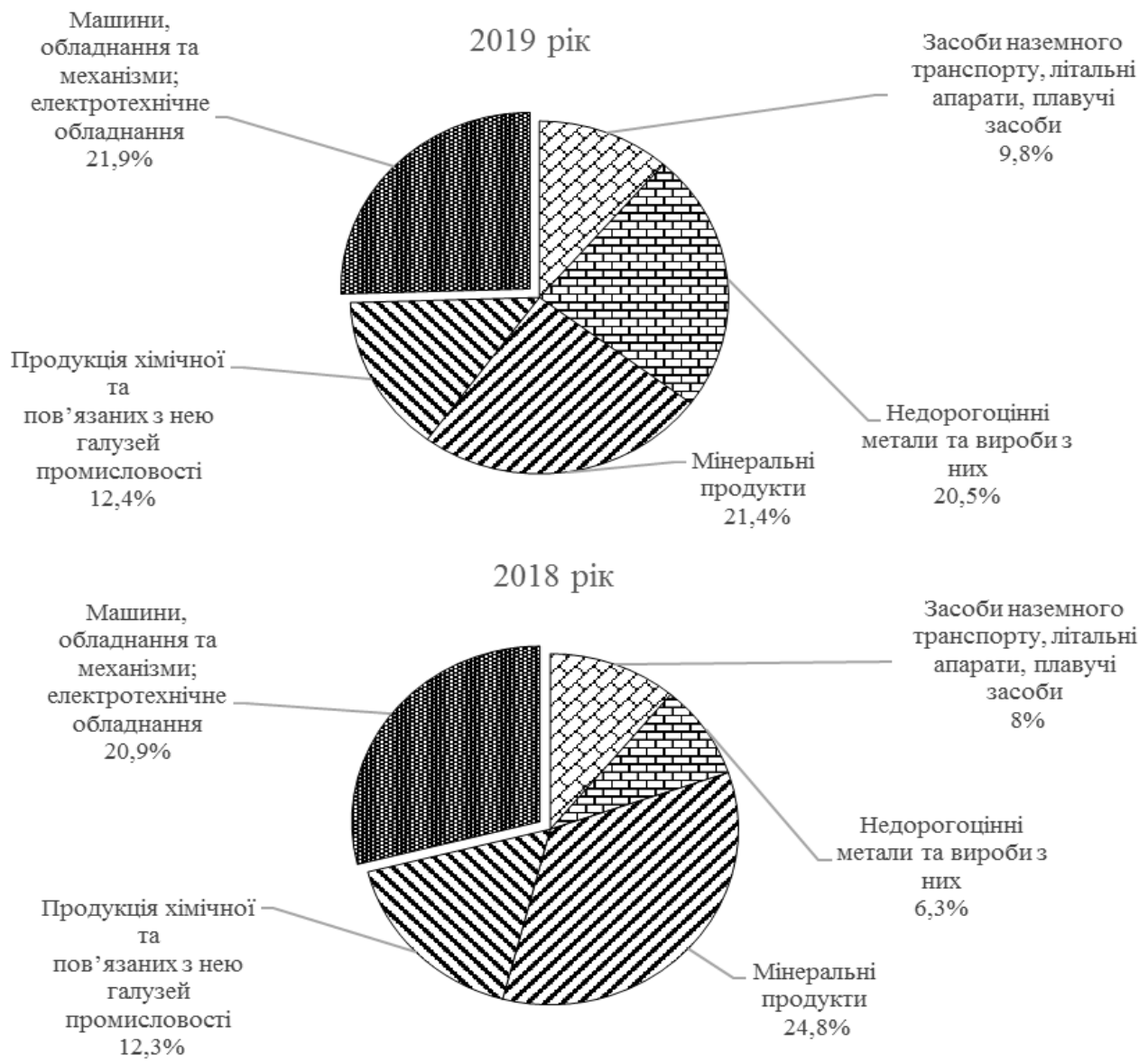

Рис. 5. Товарна структура імпорту України у 2018 та 2019 рр.

Джерело: побудовано авторами за даними Державної служби статистики України (Державна служба статистики України, n.d.)

У 2019 р. експорт послуг становив 15237,5 мин дом. США або 130,9 \% у порівнянні з 2018 р., імпорт - 6527,9 мАн дом. США або 103,5 \%. Позитивне сальдо становимо 8709,6 млн дом. США, що на 64 \% бімьше показника 2018 р. (5329,1 мкн дом. США).

Найбільшу частку серед статей експортованих послуг у 2019 р. займають транспортні послуги, їх доля скмала 59,3\% або 9036 млн доц. США. Досить велику долю експорту мають послуги у сфері телекомунікації, комп'ютерні та інформаційні послуги (16\%) та послуги з переробки матеріальних ресурсів $(10,7 \%)$.

Основним користувачем наданих Україною послуг у 2019 р. стала Російська Федерація: майже $41 \%$ реалізованих закордоном послуг (6181,6 млн дом. США) були надані даній країні. Транспортні послуги займають
97,3 \% (6014 мкн дом. США) від усіх наданих РФ послуг.

Значна вартість наданих послуг припадає на США (8\%). Послуги у сфері телекомунікації, комп'ютерні та інформаційні послуги традиційно мали доволі великий попит на ринку Сполучених Штатів: 66,8 \% всіх наданих країні послуг припали саме на дану сфеpy.

На рис. 6 показані частки наданих посмуг та реалізованих закордоном товарів у загальному обсязі експорту України.

За результатами дослідження встановмено, що домя послуг у складі експорту в 2019 р. складає 21,4 \%, що значно переважає показники 2017 та 2018 рр. За період 2017-2019 рр. сальдо від торгівлі послугами є позитивним та збільшується с кожним роком: 5238,2 мин дол. США у 2017 р., 5329,1 мин дом. США у 2018 р. та 8709,6 млн дом. США у 


\section{9 p.}

Серед отриманих Україною від нерезидентів послуг велику частку займають транспортні послуги (зокрема послуги повітряного транспорту), послуги, пов'язані з подорожами та ділові послуги. Основними пос- тачальниками послуг до України у 2019 р. стали Сполучене Королівство Великої Британії та Північної Ірцандії - 9 \% (основні послуги - транспортні), Туреччина - 8,5 \% (послуги, пов'язані з подорожами) та Німеччина 7 \% (транспортні послуги).

\section{PIK}

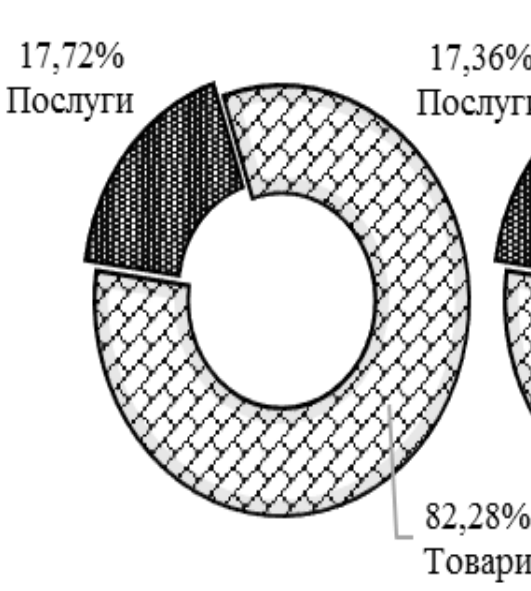

2018 PIK

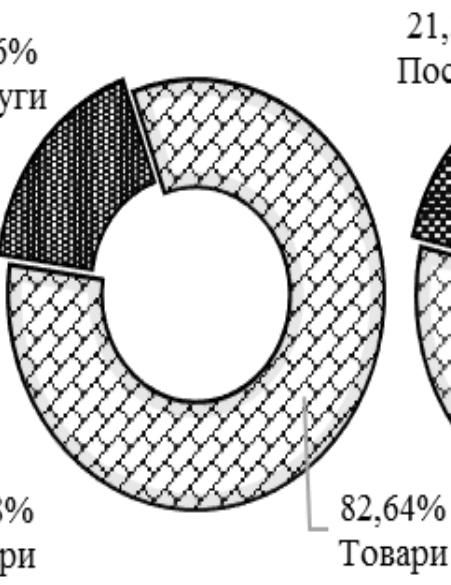

2019 PIK

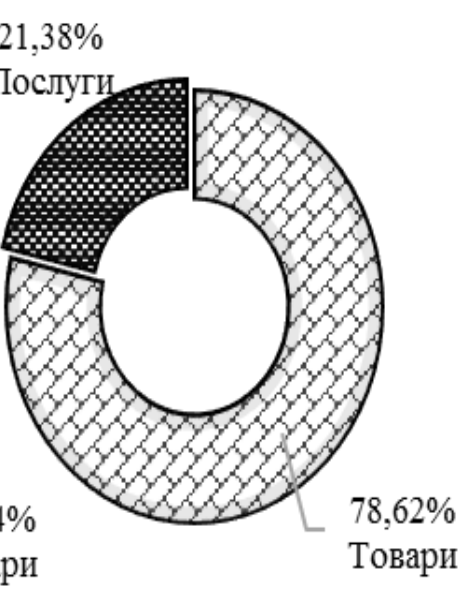

Рис. 6. Структура експорту України у 2017-2019 pр.

Джерело: побудовано авторами за даними Державної служби статистики України (Державна скужба статистики України, n.d.)

Загальний обсяг експорту товарів та послуг до країн СНД у 2019 р. склав 13267 млн дом. США, що складає 20,3 \% від всього експорту України. У 2018 р. до країн СНД було експортовано $18,2 \%$ товарів та послуг на суму 10726 млн дол. США. Отже, за аналізований період експорт товарів та послуг до країн СНД зріс на 23,6 \%.

Загальний обсяг експорту товарів та послуг до ЄC у 2019 р. склав 23994,8 ммн дол. США, що складає 37,7 \% від всього експорту України. У порівнянні з 2018 р. експорт до ЄС зріс на 3,8 \%, проте його частка в загальному обсязі експортованих Україною товарів та послуг скоротилась на 2,6\%. Основними країнами-імпортерами української продукції в ЄС є Польща (майже $16 \%$ від всього експорту товарів до (С), Ітамія $(11,7 \%)$, Німеччина $(11,5 \%)$. Значно підвищились обсяги експорту вітчизняної про-

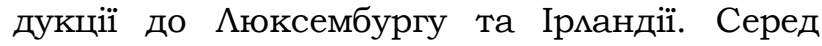
країн ЄС головними користувачами українських послуг у 2019 р. були Сполучене Коромівство Вемикої Британії та Північної Ірландії, послуги у сфері телекомунікації, комп'ютерні та інформаційні послуги мали найбільший попит на даному ринку.

Обсяги імпорту товарів та послуг з країн СНД у 2019 р. склав 12383 млн дол. США, що на $11 \%$ менше за показник 2018 р. Частка імпортних операцій з країн СНД скоротилась $321,9 \%$ у 2018 р. до 18,4 \% у 2019 р.

Імпорт товарів та послуг з країн $Є \mathrm{C} \mathrm{y}$
2019 р. збільшився за рік на $7,5 \%$ та склав 28557,3 мАн дол. США, що дорівнює 42,4 \% від загального обсягу імпорту. У 2018 р. імпорт з країн ЄС займав 41,8 \% всіх придбаних закордоном Україною послуг та товарів. Основними країнами імпорту продукції у 2019 р. були Німеччина та Польща. Вагому частку в товарній структурі імпорту з країн ЄС у 2019 р. мали продукція хімічної промисловості, машини, обладнання та механізми, засоби наземного транспорту, електротехнічне обладнання, цітальні апарати, плавучі засоби та палива мінеральні, нафта і продукти ії перегонки. Варто також відмітити збільшення майже у 2 рази імпорту з країн $Є С$ овочів та свинцю.

Серед найбільших постачальників послуг для України серед країн СС були такі країни, як: Сполучене Королівство Великої Британії та Північної Ірландії, Німеччина та Кіпр.

Перевищення обсягів наданих послуг над отриманими є фактором, який деякою мірою нівелює негативне сальдо зовнішньої торгівлі товарами. Сфера послуг має потенціал у напрямі збільшення пропозиції для зовнішнього ринку та розширення можливостей їх надання.

Підсумовуючи все вищезазначене, можна зробити висновок, що, не зважаючи на значне зростання вартості експорту товарів та послуг до країн світу, Україна все ще замишається імпортозалежною країною. Спостерігається зростання залежності промис- 
мовості України від придбаних закордоном комплектуючих, сировини та матеріалів у таких галузях, як видобування енергетичних матеріалів, мегкій промисловості, машинобудуванні, хімічній та нафртохімічній промисмовості.

Валютна мібералізація сприяла частковому уникненню упередженого ставлення 3 боку іноземних контрагентів, інвесторів та банків, що дозволило українським підприємствам вести повноцінну діяльність на зовнішніх ринках, результатом чого стало значне скорочення негативного зовнішньоторговельного сальдо країни. Новий закон про валюту забезпечив в Україні базу для вільного руху капіталу, що наблизимо країну до європейських стандартів. Проте, не зважаю- чи на значні послаблення у валютному регумюванні, українські виробники продовжують зіштовхуватися з низкою як внутрішніх, так і зовнішніх перешкод на шляху до активізації експортної діяльності (табл. 3).

Зазначені чинники у підсумку призводять до недовіри збоку закордонних партнерів щодо виконання українськими підприємствами вимог укладених контрактів та недостатньої для задоволення потреб закордонного користувача якості експортованої продукції, що веде до їі неконкурентоспроможності на іноземному ринку. Окрім того, українські підприємства зіштовхуються із пробцемами при виході на закордонні ринки через нестачу фінансів та відсутність намежної інформації про потенційний ринок.

Таблиця 3

Основні чинники, що перешкоджають експортній діяльності

українських підприємств

\begin{tabular}{|c|c|}
\hline Група чинників & Чинники \\
\hline Політичні & $\begin{array}{ll}\text { - } & \text { нестабільна політична ситуація в Україні; } \\
\text { - } & \text { корупція в державному секторі. }\end{array}$ \\
\hline $\begin{array}{l}\text { Організаційно- } \\
\text { управлінські }\end{array}$ & $\begin{array}{ll}\text { - } & \text { недосконалість законодавчої бази у сфері ЗЕД; } \\
\text { - } & \text { неефективність системи менеджменту ЗЕД; } \\
\text { - } & \text { неефективність організації виробничого процесу. }\end{array}$ \\
\hline Виробничі & $\begin{array}{l}\text { - } \quad \text { недостатній технологічний розвиток у порівнянні з розвинутими } \\
\text { країнами; } \\
\text { - } \quad \text { висока матеріаломісткість продукції; } \\
\text { - } \quad \text { низький рівень оновлення основних засобів; } \\
-\quad \text { використання неякісної сировини та матеріалів. }\end{array}$ \\
\hline Фінансові & $\begin{array}{ll}\text { - } & \text { висока інфмяція; } \\
\text { - } & \text { низька рентабельність виробництва. }\end{array}$ \\
\hline Трудові & $\begin{array}{ll}\text { - } & \text { недостатня кваліфікація персоналу; } \\
\text { - } & \text { несприятлива демографічна ситуація в Україні; } \\
\text { - } & \text { низька продуктивність праці. }\end{array}$ \\
\hline
\end{tabular}

Джерело: побудовано авторами на основі (Аеоненко, 2005; Манаєнко, 2018; Беглов, 2020; Касич, 2020)

Очевидно, що стабільний розвиток економіки можливий мише при збереженні їі відкритості та швидкому розвитку зовнішньої торгівлі. Важливо підвищити цінову конкурентоспроможність вітчизняного експорту, стимулювати експорт високотехнологічної продукції, продукції хімічної промисмовості та забезпечувати захист виробництв, що $\epsilon$ потенційно конкурентоспроможними на внутрішньому і зовнішньому ринках.

Дия захисту вітчизняних виробників використовується широкий арсенал засобів: тарифне регулювання, антидемпінгові, спеціальні та компенсаційні мита, нетарифні обмеження.

Саме державне регулювання сприяє підвищенню експорту продукції та обмеженню імпорту шияхом введення квот і обмежень. Належна реалізація програми захисту вітчизняних виробників здатна покращити економіку України, дозволить подомати сировинну залежність і створити умови дмя просування українських підприємств на зовнішні ринки.

Необхідно відзначити, що саме низький рівень конкурентоспроможності продукції перешкоджає повноцінному виходу вітчизняних виробників на зовнішній ринок, окрім того, чимало української продукції витісняється 3 внутрішнього ринку (Череп, 2016). Тому важливим аспектом для вироблення ефективної зовнішньоекономічної стратегії 
підприємств є аналіз ринків збуту, який передбачає маркетингові дослідження. Повинен проводитися аналіз географіiі, специфічних особливостей і вимог ринків збуту, можмивих змін у величині та характері попиту. Відповідно, експортна поцітика підприємст- ва вибудовується після виявлення перспектив реалізації конкретної продукції на певних ринках. Сьогодні на міжнародний бізнес впливає ряд значущих чинників. На рис. 7 представцено їх значення дия компаній, які планують міжнародну діяльність.

\begin{tabular}{|c|c|c|c|}
\hline $\begin{array}{c}\text { Підвищення } \\
\text { гмобамізації } \\
\text { економіки }\end{array}$ & $\begin{array}{c}\text { Розвиток } \\
\text { інноваційних } \\
\text { техномогій }\end{array}$ & $\begin{array}{c}\text { Поява економіки } \\
\text { знань }\end{array}$ & $\begin{array}{c}\text { Поява нових } \\
\text { організаційних } \\
\text { форм }\end{array}$ \\
\hline $\begin{array}{l}\text { •послаблення } \\
\text { бар'єрів дия } \\
\text { міжнародної } \\
\text { діяльності; } \\
\text { •посилення } \\
\text { конкуренціі; } \\
\text { •зміна очікувань } \\
\text { споживачів. }\end{array}$ & $\begin{array}{l}\text { •бурхливий } \\
\text { розвиток } \\
\text { Інтернету; } \\
\text { •зміна природи } \\
\text { маркетингу. }\end{array}$ & $\begin{array}{l}\text { •ріст затрат на } \\
\text { НДДКР; } \\
\text { •швидке } \\
\text { застарівання } \\
\text { техномогій; } \\
\text { •скорочення } \\
\text { життеєвого циклу } \\
\text { товара. }\end{array}$ & $\begin{array}{l}\text { •мережеві форми } \\
\text { кооперації між } \\
\text { підприємствами; } \\
\text { •віртуальні } \\
\text { підприємтсва. }\end{array}$ \\
\hline
\end{tabular}

Рис. 7. Сучасні тенденції здійснення бізнесу та їх вплив на підприємства, що виходять на міжнародний ринок

Джерело: побудовано авторами на основі (Череп, 2016; Онищенко, 2015)

Однак ці тенденції можуть нести у собі як нові можливості, так і загрози для українських підприємств. Наприклад, посилення процесу глобалізації сприяє мібералізації торгівлі, створенню єдиних економічних і правових стандартів, бізнес-центрів, які надамі можуть дати шанс навіть дрібним підприємствам реалізувати свій бізнес в іншій країні. 3 іншого боку, посилення глобалізаційних процесів веде до підвищення конкуренції, внаслідок чого продукція та послуги багатьох підприємств можуть залишитись без достатньої потреби на новому ринку.

Крім того, з розширенням глобалізації, з'являється можливість вибору безлічі товарів і послуг як на глобальному, так і на місцевому ринку, у зв'язку з чим зростають очікування споживачів та їх вимоги до продукції (Обуд, 2017). У сучасному суспільстві змінюється багато аспектів ведення бізнесу: інтернет, мобільний зв'язок та інші засоби комунікації сприяють розвитку економічно вигідних організаційних структур, а підприємства, у свою чергу, реагують на ці зміни й пристосовуються до нових потреб споживачів. Варто враховувати вплив інформаційних технологій на природу маркетингу, оскільки покупці звикли обирати необхідні товари, враховуючи їх якість та відгуки про підприємство. Сьогодні через Інтернет зробити покупку набагато дешевше і зручніше, незалежно від того, в якій країні покупець живе. У зв'язку з цим, багато вемиких під- приємств мають шанс дмя завоювання міжнародного ринку. Цьому сприяє розвиток маркетингових, технологічних, інтелектуальних можиивостей, а також співпраця 3 іншими компаніями, яка може привести до створення спільних підприємств та відкриття нових мереж. Можливість створення організаційних форм приваблює багато фірм, адже це допомагає їм не тільки розширити спектр послуг і залучити нових клієнтів, але й обмінюватися інформацією один з одним i брати участь в спільних наукових розробках, тим самим сприяти освоєнню нових галузей на міжнародному ринку.

Висновки. Отже, за результатами проведених досміджень можна виділити наступні шияхи розвитку вітчизняних підприємств, які сприятимуть активізації їх зовнішньоекономічної діяльності: оновлення виробничих фондів; впровадження новітніх технологій виробництва; підвищення рівня конкурентоспроможності продукції та доведення рівня іiї якості до світових стандартів; підвищення наукомісткої продукції у виробництві та експорті; широке застосування маркетингу та менеджменту у сфері ЗЕД; замучення іноземних інвестицій у виробництво; застосування сучасних форм управління та організації виробництва; підвищення рівня кваліфікації персоналу; створення підприємствами спілок виробників і експортерів; державна підтримка ЗЕД. 


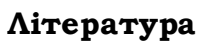

1. Власюк О. С. Виклики та загрози фінансової безпеки України на середньострокову перспективу. Фінанси України. 2012. № 5. С. 3-13.

2. Диба О. М. Інноваційний розвиток підприємств в умовах глобалізації. Стратегія економічного розвитку України. 2018. № 42. С. 111-118.

3. Дроздова Г. М. Менеджмент зовнішньоекономічної діяльності підприємства. К. : Центр учбової мітератури, 2012. 382 с.

4. Кірієнко О. М. Вплив глобальних світових тенденцій на розвиток економіки України. Вісник Придніпровсъкої державної академї будівниитва та архітектури. 2013. № 6. С. 39-43.

5. Міжнародні стратегії економічного розвитку / за ред. Ю. Г. Козак, В. В. Ковалевський, О. В. Захарченко. К. : Аварио, 2011. 256 с.

6. Міжнародна торгівця / Ю. Г. Козак та ін. К. : Центр учбової цітератури, 2015. 272 с.

7. Рзун И. Г., Старкова Н. О. Управление конкурентоспособностью региона. Вестник НГИЭИ. 2016. № 11. С. 89-99.

8. Трифонова О.В., Швець В. Я.Основи зовнішньоекономічної діяльності. К. : Професіонал, 2015. 152 c.

9. Васюренко В. О. Фінансове регулювання ЗЕД підприємств: теоретичне узагальнення та прикладний аналіз: монографія. Харків : ХНЕУ, 2012. 100 с.

10. Чепінога В. Г. Основи економічної теорії. К. : Аіра-К, 2017. 240 с.

11. Про валюту і валютні операції : Закон України від 21 червня 2018 р. № 2473-VIII / Верховна Рада України. URL: https://zakon.rada.gov.ua/laws/show/2473-19 (дата звернення: 15.03.2020).

12. Про внесення зміни до Положення про заходи захисту та визначення порядку здійснення окремих операцій в іноземній валюті : Постанова НБУ від 18 червня 2019 р. № 78 / Національний Банк України. URL: https://zakon.rada.gov.ua/laws/show/v0078500-19 (дата звернення: 15.03.2020).

13. Зовнішньоторговельний баланс України у 2019 році: експрес-випуск / Державна служба статистики України. URL: http://www.ukrstat.gov.ua/express/expr2020/02/14.pdf (дата звернення: 15.03.2020).

14. Статистична інформація. Державна служба статистики Ужраїни : веб-сайт. URL: http://www.ukrstat.gov.ua/ (дата звернення: 20.02.2020).

15. Зовнішня торгівця України товарами у 2019 році: експрес-випуск / Державна служба статистики України. URL: http://www.ukrstat.gov.ua/express/expr2020/02/15.pdf (дата звернення: 20.02.2020).

16. Аеоненко П. М., Черепніна О. І. Зовнішньоекономічна діяльність України: сучасні тенденції. Актуальні проблеми економіки. 2005. № 2. С. 75-84.

17. Манаєнко I. М., Просяник I. В. Особливості зовнішньоекономічної діяльності вітчизняних підприємств в умовах євроінтеграції. Науковий вісник Ужгородсъкого національного університету. 2018. № 18. C. 11-14. URL: https://dspace.uzhnu.edu.ua/jspui/handle/lib/23864 (дата звернення: 15.03.2020).

18. Беглов О. В., Пантелеєв В. П. Проблеми забезпечення конкурентоспроможності підприємств України в умовах глобалізації. Стратегічні пріоритети розвитку економіки, обліку, фінансів та права в Україні та світі : збірник тез доповідей міжнар. наук.-практ. конф., м. Полтава, 23 січня 2020 р. Полтава, 2020. С. 8-10.

19. Касич А. О., Бабич Ю. А. Зовнішній аспект аналізу експортного потенціалу металургійних підприємств України. Iнвестииї̈: практика ma досвід. 2020. № 3. C. 27-31. URL: http://www.investplan.com.ua/pdf/3_2020/7.pdf (дата звернення: 15.03.2020).

20. Череп О. Г. Конкурентоспроможність продукції підприємств машинобудування в період євроінтеграції України в Європейський Союз. Вісник Приазовського державного технічного університету. 2016. № 31. C. 46-53. URL: http://nbuv.gov.ua/UJRN/VPDTU_ek_2016_31\%281\%29_7 (дата звернення: 15.03.2020).

21. Онищенко В. П. Сучасні організаційні форми та моделі міжнародного бізнесу. Зовнішня торгівля: економіка, фінанси, право. $2015 . \quad$ № 3. $\quad$ C. $20-31$ URL: http:/ /zt.knteu.kiev.ua/files/2015/3(80)/uazt_2015_3_4.pdf (дата звернення: 15.03.2020).

22. Федулова $\Lambda$. I., Корнєєва Т. М. Державна політика розбудови економіки знань: особливості реалізації антикризової стратегії. Фінанси України. 2009. № 10. C. 3-17. URL: http://nbuv.gov.ua/UJRN/Fu_2009_10_2 (дата звернення: 15.03.2020).

23. Обуд О. П. Нові тренди у поведінці сучасних споживачів. Сучасні тренди поведінки споживачів товарів і послуг : матеріали міжнародної наук.-практ. конф., м. Рівне, 15-16 грудня 2017 р. Рівне : РДГУ, 2017. С. 90-92. 


\section{References}

1. Vlasyuk, O. S. (2012). Challenges and threats to the financial security of Ukraine in the medium term. Finance of Ukraine, 5, 3-13. (in Ukrainian)

2. Dyba, O. M. (2018). Innovative development of enterprises in the context of globalization. Strategy of Economic Development of Ukraine, 42, 11-118. Retrieved from http://nbuv.gov.ua/UJRN/seru_2018_42_12. (in Ukrainian)

3. Drozdova, G. M. (2012). Management of foreign economic activity of the enterprise. Kiev: CUL. (in Ukrainian)

4. Kirienko, O. N. (2013). Influence of global world tendencies on development of economy of Ukraine. Bulletin of Prydniprovs'ka State Academy of Civil Engineering and Architecture, 6, 39-43. Retrieved from: http://nbuv.gov.ua/UJRN/Vpabia_2013_6_10. (in Ukrainian)

5. Kozak, Y. G. (2011). International economic development strategies. Kiev: Avario. (in Ukrainian)

6. Kozak, Y. G. (2015). International Trade. Kiev: CUL. (in Ukrainian)

7. Rzun, I. G., \& Starkova, N. O. (2016). Management of competitiveness of the region. Bulletin NGIEI, 11, 89-99. (in Russian)

8. Trifonova, V. V. (2015), Bases of foreign trade activities. Kiev: Professional. (in Ukrainian)

9. Vasyurenko, V. O. (Ed.). (2012). Financial regulation of foreign economic activity of enterprises. Kharkiv. (in Ukrainian)

10. Chepinoga, V. G. (2017). Basics of economic theory. Kiev: Lyra-K. (in Ukrainian)

11. Pro valiutu i valiutni operatsii: Zakon Ukrainy vid 21 chervnia 2018 r. Retrieved from https://zakon.rada.gov.ua/laws/show/2473-19. (in Ukrainian)

12. Pro vnesennia zminy do Polozhennia pro zakhody zakhystu ta vyznachennia poriadku zdiisnennia okremykh operatsii v inozemnii valiuti : Postanova NBU vid 18 chervnia 2019 № 78 / Natsionalnyi Bank Ukrainy. Retrieved from https://zakon.rada.gov.ua/laws/show/v0078500-19. (in Ukrainian)

13. State Statistics Service of Ukraine. (n.d.). Foreign Trade Balance of Ukraine in 2019: Express Release. Retrieved from http://www.ukrstat.gov.ua/express/expr2020/02/14.pdf. (in Ukrainian)

14. State Statistics Service of Ukraine. (n.d.). Retrieved from http://www.ukrstat.gov.ua. (in Ukrainian)

15. State Statistics Service of Ukraine. (n.d.). Foreign Trade of Ukraine in 2019: Express Release. Retrieved from http://www.ukrstat.gov.ua/express/expr2020/02/15.pdf. (in Ukrainian)

16. Leonenko, P. M., \& Cherepnina, O. I. (2005). Foreign economic activity of Ukraine: modern trends. Actual Problems of Economics, 2, 75-84. (in Ukrainian)

17. Manaenko, I. M., \& Prosyanyk, I. V. (2018). Features of foreign economic activity of domestic enterprises in the conditions of European integration. Scientific Bulletin of Uzhhorod University, 18, 11-14. Retrieved from https://dspace.uzhnu.edu.ua/jspui/handle/lib/23864. (in Ukrainian)

18. Beglov, O. V., \& Panteleev, V. P. (2020). Problems of ensuring the competitiveness of Ukrainian enterprises in the conditions of globalization. Strategic priorities for the development of economy, accounting, finance and law in Ukraine and the world: a collection of abstracts inter. Research Practice Conf. (pp. 8-10). Poltava. (in Ukrainian)

19. Kasych, A. O., \& Babych, Y. A. (2020). External aspect of analysis of export potential of metallurgical enterprises of Ukraine. Investment: practice and experience, 3, 27-31. Retrieved from http://www.investplan.com.ua/pdf/3_2020/7.pdf. (in Ukrainian)

20. Cherep, O. G. (2016). Competitiveness of machine-building enterprises in the conditions of European integration of Ukraine. Bulletin of Azov State Technical University, 31, 46-53. Retrieved from http://nbuv.gov.ua/UJRN/VPDTU_ek_2016_31\%281\%29_7. (in Ukrainian)

21. Onishchenko, V. P. (2015). Modern organizational forms and models of international business. Foreign trade: economics, finance, law, 3, 20-31. Retrieved from http://zt.knteu.kiev.ua/files/2015/3(80)/uazt_2015_3_4.pdf. (in Ukrainian)

22. Fedulova, L. I., \& Korneeva, T. M. (2009). State policy of developing the knowledge economy: features of the implementation of the anti-crisis strategy. Finance of Ukraine, 10, 3-17. Retrieved from http://nbuv.gov.ua/UJRN/Fu_2009_10_2. (in Ukrainian)

23. Obud, O. P. (2017). New trends in the behavior of modern consumers. Modern trends in consumer behavior of goods and services: materials of international scientific-practical. Conf. (pp. 90-92). Rivne: RDGU. (in Ukrainian) 